\title{
Resorbed or Dead Litter
}

National Cancer Institute

\section{Source}

National Cancer Institute. Resorbed or Dead Litter. NCI Thesaurus. Code C124618.

A pregnancy result for a female that had all intrauterine deaths. 